\title{
Spatial variability in recolonisation potential: influence of organism behaviour and hydrodynamics on the distribution of macrofaunal colonists
}

\author{
Carolyn J. Lundquist ${ }^{*}$, Simon F. Thrush, Judi E. Hewitt, Jane Halliday, \\ Iain MacDonald, Vonda J. Cummings
}

National Institute of Water and Atmospheric Research, PO Box 11-115, Hamilton 3251, New Zealand

\begin{abstract}
Estuaries are dynamic environments in which human and natural disturbances can result in clearing or smothering of soft-sediment communities. Hydrodynamic models simulating organism transport predict that recovery potential of benthic communities will be affected by: (1) location within an estuary, (2) proximity to the source of colonists and (3) the relative buoyancy and life-history strategies of colonists. To test these predictions, we deployed sediment traps daily at 7 locations for $7 \mathrm{~d}$ across a range of habitat types within a tidally dominated estuary, to estimate the pool of available colonists. Our results confirmed model predictions in that location strongly influenced the number of trap colonists. In particular, sandflat sites received more trap colonists than tidal creek sites. Most trap colonists were either juvenile or adult life stages. Species collected in traps differed from the benthic communities in the surrounding sandflat in that bivalves were overrepresented and polychaetes were under-represented. Most bivalve colonists were collected as postsettlement juveniles, indicating post-settlement dispersal (byssal-thread drifting or bedload transport) as a primary means of transport. Polychaetes with adult swimming stages were collected in the traps, while tube-dwelling polychaetes were rarely collected. Organism transport and sediment deposition were highest during a wind-wave event. This research demonstrates the value of linking biology and hydrodynamic modelling to predict the potential pool of colonists available for recolonisation, and thus determine thresholds in the recovery from disturbance on an estuary-wide scale.
\end{abstract}

KEY WORDS: Estuary · Recolonisation · Recovery $\cdot$ Disturbance $\cdot$ Transport

\section{INTRODUCTION}

Estuaries are subject to a wide range of natural and human impacts, including increasing rates of terrestrial sediment deposition and suspended sediment concentrations related to development in surrounding catchments. Temporal scales of disturbances range from short-term catastrophic to long-term cumulative effects (Ellis et al. 2000, Thrush et al. 2003). Some disturbances result in smothering of benthic communities (e.g. sedimentation events), while others (e.g. dredging, cockle harvesting) disrupt sediment stability (Ellis et al. 2000). To predict how benthic communities recover from disturbance, we need to understand the dispersal patterns of different life stages of benthic organisms which help us to anticipate the spatial and temporal patterns in the pool of colonists available for recolonisation of disturbed sites.

Different life stages may contribute to dispersal and recolonisation in estuaries, and the composition of colonists may differ based on size and timing of disturbance (Thrush \& Whitlatch 2001). Colonisation potential may differ seasonally, with some taxa dispersing only as larvae. Non-planktonic larval dispersal is common in soft-sediment systems (Grantham et al. 2003), with crawling and brooded larvae dispersing relatively short distances from release. Post-settlement dispersal, both as bedload and in the water column (often using 
byssal or mucous threads), has been observed in many estuarine bivalves and in other taxa (Beukema \& de Vlas 1989, Pridmore et al. 1991, Cummings et al. 1993, Commito et al. 1995b, Hewitt et al. 1997). Finally, colonisation by adults through crawling or burrowing through the substrate or swimming is often responsible for initial establishment of small patches (Thrush \& Whitlatch 2001).

Numerous field experiments document impacts and recovery rates of various disturbances at small scales (Thrush et al. 1991, 1996, 1998, 2003, Norkko \& Bonsdorff 1996, Shull 1997, Norkko et al. 2002, Hewitt et al. 2003, Zajac \& Whitlatch 2003). Our goal was to extrapolate beyond small experimental plots to the landscape scale to estimate how spatial and temporal variability in the pool of colonists influences recovery potential at an estuary-wide scale. One way to extrapolate beyond the scale of field experiments is to use hydrodynamic models to predict recolonisation by simulating dispersal of organisms under varying wind, wave and tidal conditions. Models for specific taxa have been used to predict larval, juvenile and adult distributions of estuarine fish and invertebrates, and transport of both larval and post-settlement stages (Verdier-Bonnet et al. 1997, Blanton et al. 1999, Ellien et al. 2000). Most models are primarily subtidal, and concern large fish and invertebrate species of commercial interest with relatively long planktonic dispersal periods. However, a large proportion of benthic soft-sediment communities have short or no planktonic dispersal periods (mean of $66 \%$, with non-planktonic larval development for soft-sediment intertidal communities in California and Washington; Grantham et al. 2003). Temporal distributions of colonists also differ, particularly for species with planktonic larvae. Thus, to understand estuarine community recovery we need to understand recovery dynamics encompassing either organisms with extensive or limited dispersal potential. In addition, the presence of different dispersing life stages (larvae, juveniles, adults) can reveal the relative influence of colonisation from local and regional (larval) pools.

One existing model has predicted recovery potential for a range of dispersal strategies at multiple locations within a shallow New Zealand estuary (Lundquist et al. 2004b). By simulating dispersal of different larval and post-settlement juvenile benthic organisms, the model predicted recruitment limitation for 3 hypothesised dispersal strategies at all of the estuarine locations modelled (Lundquist et al. 2004b). The model generated testable differences in colonist pools at sites that vary in exposure to wind-generated waves and tidal currents, predicting that the recovery potential of benthic communities would be affected by: (1) location with respect to hydrodynamic processes, (2) proximity to source locations of colonists and (3) relative buoyancy and life-history strategies of colonists (Lundquist et al. 2004b). For example, exposed estuarine sandflats are predicted to receive more colonisers than sheltered high intertidal areas such as mudflats and tidal creeks, and strong tidal currents during spring tides would lead to higher transport rates than during neap tides and calm conditions. Sites close to channels are also predicted to have lower colonisation rates, resulting from high current rates that keep particles and organisms entrained in the water column and prevent deposition.

With the predictions of the model in mind, we designed a field experiment to explore spatial differences in recolonisation potential in another estuary. Our goals were to test model predictions of areas or habitats that are most, or least, likely to recover based on both the biological and physical characteristics of the location. We addressed 3 model predictions in this study. First, does the available colonist pool, as represented by colonists passing over the sites, differ between sites? We looked at both the influence of physical parameters, such as tidal conditions, channel morphology and depth on transport, and also how stochastic events such as storm-generated waves differ in their spatial and temporal effects on transport. We predicted that exposed sites (open sandflats) would have larger rates of colonisation compared to protected sites (tidal creeks) and that colonist pools within sites would also differ temporally based on exposure to windwaves and strong tidal currents that increase rates of transport. Second, we examined the influence of the ambient community on the pool of colonists, and compared contributions to colonisation from local and outside sources as a surrogate for proximity to source populations. We predicted that colonists at sheltered sites would be most similar to their ambient communities, reflecting restricted supply, while exposed sites would receive colonists from both local and regional colonist pools. We also predicted that colonisation rates by post-settlement juveniles and adults would be larger than that by larvae, reflecting recruitment limitation as predicted by the model at all sites. Finally, we investigated whether organisms are differentially susceptible to transport, comparing available colonists at different heights in the water column to extrapolate to potential distances transported.

\section{MATERIALS AND METHODS}

Study area. The experiment was undertaken in the Whitford embayment (36 $\left.54^{\circ} \mathrm{S} 174^{\circ} 58^{\prime} \mathrm{E}\right)$, Auckland, New Zealand (Fig. 1) during austral summer, when larval and post-settlement juvenile colonists are com- 


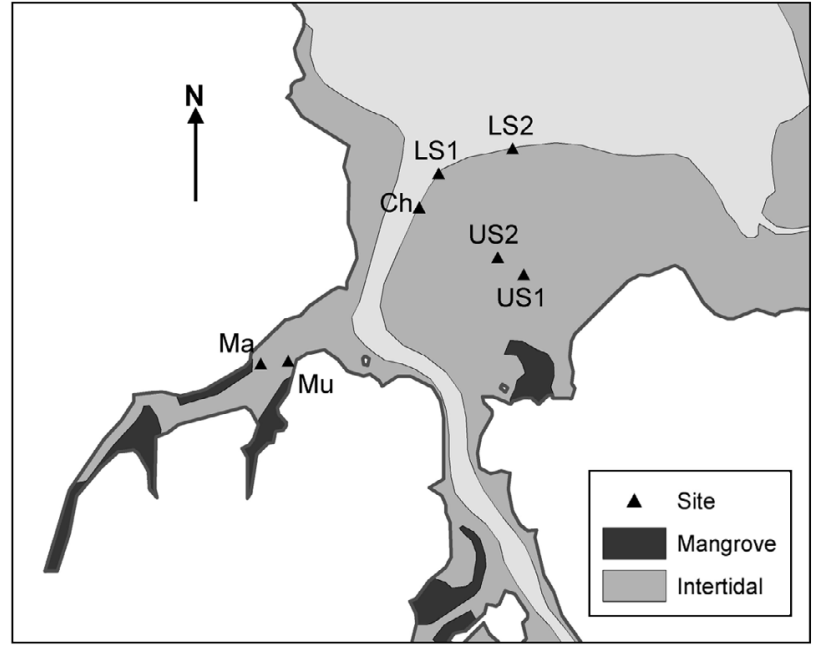

Fig. 1. Sampling site locations in Whitford embayment, Auckland, New Zealand: Upper Sandflat 1 (US1), Upper Sandflat 2 (US2), Channel (Ch), Lower Sandflat 1 (LS1), Lower Sandflat 2 (LS2), Mud (Mu) and Mangrove (Ma). DOBIE wave gauges were located at all sites, except site Ma. ADVs were located at sites US1 and Ch

monly available. Two-dimensional, depth-averaged hydrodynamic models were used to select 7 intertidal sites in the main embayment and associated tidal creeks that were predicted to vary in availability of benthic colonists (for detailed hydrodynamic and particle tracking model descriptions see Lundquist et al. 2004 b). The hydrodynamic model was calibrated against field measurements of bathymetry, wave pressure and tidal currents over a range of hydrodynamic conditions. A particle tracking model simulated 3-dimensional movement of neutrally buoyant particles, partitioning depth into 10 variable thickness layers. Particles were released from the grid cell containing each site and tracked over 2 tidal cycles to simulate the relative availability of colonists at each site. The relative movement of particles from each release location was used to rank sites by: (1) the total percent dispersing from the release cell, (2) the percent dispersing beyond the local pool (defined as beyond $200 \mathrm{~m}$ from the release cell) and (3) the percent remaining inside the local pool (defined as all particles remaining within the same depth range as the release cell with respect to Chart Datum (CD): high intertidal, $>2 \mathrm{~m}$ above $\mathrm{CD}$; midintertidal, 1 to $2 \mathrm{~m}$ above $\mathrm{CD}$; low intertidal, 0 to $1 \mathrm{~m}$ above $\mathrm{CD}_{\text {; }}$ subtidal, below $\mathrm{CD}$ ). Five 'Sandflat' sites (Lower Sandflat 1: LS1; Lower Sandflat 2: LS2; Channel: Ch; Upper Sandflat 1: US1; Upper Sandflat 2: US2) were located in the main Whitford embayment, each at a different distance from the main channel and therefore differing in immersion time (Fig. 1). Two sites (Mud: $\mathrm{Mu}$; Mangrove: Ma) were in Mangemangeroa Creek, 1 of 3 tidal creeks flowing into the Whitford embayment (Fig. 1). The mangrove site was adjacent (within $10 \mathrm{~m}$ ) to the edge of a mangrove Avicennia marina forest.

Sediment traps. Cylindrical sediment traps were used to collect sediment and organisms transported in the bedload and in the water column. The sediment traps provide a surrogate for potentially available colonists by estimating the total flux of sediment and organisms passing over each trap location (Commito et al. 1995b, Turner et al. 1997). Traps also allowed comparisons of material available at different heights in the water column to estimate proportions of organisms/sediment dispersing in the bedload or in the water column. Three replicates, separated by $10 \mathrm{~m}$, of 3 trap types (1 each of bedload, $5 \mathrm{~cm}$ water column and $15 \mathrm{~cm}$ water column traps) were deployed at each site (9 traps site $^{-1}, 63$ traps total). Sediment traps were composed of an external sleeve constructed of PVC pipe (internal diameter $=6.5 \mathrm{~cm}$; length $=55 \mathrm{~cm}$ ), and were dug directly into the sediment. An internal trap (internal diameter $=4 \mathrm{~cm}$; length $=50 \mathrm{~cm}$; aspect ratio $=12.5$ ) was screwed directly into the external sleeve such that the bedload trap was flush with the sediment surface, and the water column traps protruded 5 and $15 \mathrm{~cm}$ above the sediment surface (Commito et al. 1995b, Turner et al. 1997). External sleeves with caps to prevent sediment entry were positioned at the 7 sites in December 2001, 1 wk prior to the commencement of the experiment, to allow for stabilisation of the sediment, and they were left in place until the completion of the February 2002 sampling.

Bedload and water column traps were sampled daily during daytime low tides ( 2 tidal cycles per sample) from 10 to 14 December 2001 and from 12 to 15 February 2002. Contents of traps were rinsed into buckets and preserved in $70 \%$ isopropyl alcohol in seawater. Trap samples were stained with Rose Bengal, sieved on a $250 \mu \mathrm{m}$ mesh and sorted to enumerate macrofauna. All remaining material in each sample was dried and weighed to calculate total sediment collected by each trap. One sediment sample from each trap height for Days 1 and 2 in December was randomly chosen for detailed particle size analysis (see below).

Three core samples (13 cm diameter, $15 \mathrm{~cm}$ depth) were taken at each site at the end of each deployment period to estimate ambient macrofaunal abundance. Core samples were sieved on a $500 \mu \mathrm{m}$ mesh, stained with Rose Bengal and preserved in $70 \%$ isopropyl alcohol in seawater. Macrofauna were enumerated and identified to the lowest practicable taxonomic level.

Sediment analyses. Surficial sediment samples $(2 \mathrm{~cm}$ diameter core, $2 \mathrm{~cm}$ depth) were collected from each set of 3 trap types $\left(3\right.$ site $\left.^{-1}\right)$ at the beginning of each deployment period, to measure particle size, organic 
content and chlorophyll a content. Grain size samples were homogenised, digested in hydrogen peroxide, wet sieved and dried at $60^{\circ} \mathrm{C}$, to separate percentage weights of gravel/shell hash $(>2000 \mu \mathrm{m})$, coarse sand (500 to $2000 \mu \mathrm{m}$ ), medium sand (250 to $500 \mu \mathrm{m}$ ), fine sand $(62.5$ to $500 \mu \mathrm{m})$, silt (3.9 to $62.5 \mu \mathrm{m})$ and clay $(\leq 3.9 \mu \mathrm{m})$. Grain size analysis for material collected in sediment traps was processed using the same procedure. Samples processed for organic content were dried at $60^{\circ} \mathrm{C}$ for $48 \mathrm{~h}$ and then ashed for $5.5 \mathrm{~h}$ at $400^{\circ} \mathrm{C}$. Chlorophyll a samples were freeze-dried, weighed and homogenised. Chlorophyll a was extracted from a subsample by boiling the sediment in $90 \%$ ethanol, and the extract was processed using a spectrophotometer. An acidification step was used to separate degradation products from chlorophyll a.

Physical measurements. DOBIE-OBS wave pressure gauges (NIWA Instrument Systems) were deployed to estimate water depth and wave height by measuring water pressure. Optical back-scatter (OBS) was used to estimate suspended sediment concentration based on laboratory calibrations of sensitivity to different suspended sediment concentrations. DOBIEs were deployed at all 5 sandflat sites, and at the tidal creek mud site. DOBIEs sampled in 15 min intervals at $5 \mathrm{~Hz}$, resulting in 2048 data points per burst (6.83 $\mathrm{min}$ ). Orbital bed velocity $\left(U_{\mathrm{b}}, \mathrm{cm} \mathrm{s}^{-1}\right)$ was calculated from significant wave height, mean spectral period and mean water depth, according to the methods of Green \& Black (1999). We used $U_{\mathrm{b}}{ }^{3}$ to characterise disturbance of the seabed by waves, as time-averaged dissipation of wave energy by bed friction is proportional to $U_{\mathrm{b}}{ }^{3}$ (Nielsen 1992). ADVs (Acoustic Doppler velocimeters; Nortek Vector and Sontek ADV) were deployed at US1 and $\mathrm{Ch}$ to estimate currents caused by tides or winds. ADV sensors were located at $40 \mathrm{~cm}$ (Nortek) and $23.6 \mathrm{~cm}$ (Sontek) above the sediment surface. ADVs sampled at the same 15 min intervals as the DOBIEs, at $8 \mathrm{~Hz}$, resulting in 3280 data points per burst (6.83 min). Hourly, surface wind speed and direction were collected from the nearest Auckland Regional Council wind station at Musick Pt Ews $\left(36.8^{\circ} \mathrm{S}\right.$, $174.9^{\circ} \mathrm{E}$ ). Raw data for all physical measurements were averaged over each sediment trap collection period.

Statistical analyses. Differences between sites were assessed separately for the number of macrofauna, number of taxa and sediment weight collected in traps. We also analysed differences between the ratio of the number of macrofaunal individuals in traps with that in the ambient sediment, to see if trap samples were determined by the ambient conditions at the site. As neither raw count data nor log- or square-root-transformed data satisfied assumptions of analysis of variance and nonnormal error structures did not give good data fits, all variables were rank transformed prior to analysis.
Preliminary inspection showed significant differences for all variables between onshore and offshore wind periods (as defined by a combination of mean wave height and wind direction); thus, we used weather instead of individual sample days as a factor in our analyses. Because of a priori predictions, the analyses were conducted separately for each trap height (bedload, $5 \mathrm{~cm}$ and $15 \mathrm{~cm}$ ). Variables were analysed by a 2-factor ANOVA, with site and weather as fixed factors (SAS v 9.1). Where significant interactions were indicated, multiple comparison tests (Bonferroni) were carried out separately for each weather-trap height combination.

Multiple regression was used to identify the role of the measured environmental variables in explaining the observed spatial and temporal variability in the ratio of macrofauna in sediment traps to that in ambient cores. A backwards variable selection procedure was used to determine the subset of environmental variables that best explained the observed variability in sediment trap abundance at each trap height. Environmental variables in the analysis included physical variables calculated from DOBIEs and the wind station, and 3 rankings of dispersal potential at each site from the hydrodynamic model based on bathymetry at $200 \mathrm{~m}$ resolution of the estuary. As ADV data were only collected from 2 sites, these data were not included in the multiple regression. DOBIE and wind values were averaged over each daily sediment trap collection period. DOBIE variables included maximum depth, maximum and average values of significant wave height, maximum and average bedload velocities $\left(U_{\mathrm{b}}\right)$, and maximum and average OBS values, representing suspended sediment concentrations. Wind variables included maximum and average wind speed, direction and the number of hours of onshore winds at each site during each sampling period. Variables derived from the hydrodynamic model were: (1) the percent of particles dispersing from the release location (model: disperse); (2) the percent of particles dispersing $>200 \mathrm{~m}$ from the release location within 2 tidal cycles (model: far); and (3) the amount of between-habitat dispersal of particles, calculated as the percent of particles transported to different habitats from the release location as defined previously relative to CD (model: habitat). Multiple regression was performed using the interactive REG procedure of SAS. Results were analysed for the effects of colinearity (Belsley et al. 1980); best-fit models given were not affected by colinearity.

In addition to having different physical conditions, sites were chosen based on the presence of different ambient communities (e.g. dense cockle bed at $\mathrm{Ch}$, polychaete-dominated communities at LS1 and LS2). To determine similarities between ambient communities and macrofauna found in traps during both onshore and offshore wind periods, we performed a nonmetric, multi-dimensional scaling (MDS) ordina- 
tion using Bray-Curtis similarity indices calculated from raw and square-root-transformed count data. The MDS ordinations presented had stress levels <0.13, indicating that the MDS provided an adequate representation of the relationships between samples. Multivariate analyses were performed using the PRIMER statistical package (Clarke \& Warwick 1994).

\section{RESULTS}

\section{Site characteristics}

All sandflat sites had similar sediment composition of primarily medium and fine sands with low organic content $(<1 \%)$ (Table 1$)$. In contrast, the tidal creek sites (Mu and $\mathrm{Ma}$ ) had a high proportion of silt and clay particles (50.89 and $27.68 \%$, respectively), and had organic content of 2 to 5 times the values observed at sandflat sites. Chlorophyll a varied between 4.59 and $11.10 \mathrm{mg} \mathrm{g}^{-1}$ sediment, with the highest values observed at the tidal creek sites.

\section{Summary of water and atmospheric conditions during the experimental period}

The information collected by the wave gauges and ADVs gave us a picture of how physical conditions (tidal currents and wind-generated waves) could influence macrofaunal recolonisation. Wave character at sites was markedly influenced by onshore versus offshore wind directions. An onshore wind event occurred during the 10 to 12 December period. Although the mean and maximum wind speeds were reasonably similar during the onshore wind event (mean wind speeds of $5.6 \mathrm{~m} \mathrm{~s}^{-1}$, with gusts to $10.8 \mathrm{~m} \mathrm{~s}^{-1}$ ) compared to periods of offshore winds (mean wind speeds of $4.7 \mathrm{~m} \mathrm{~s}^{-1}$, with gusts to $12.4 \mathrm{~m} \mathrm{~s}^{-1}$ ) that occurred during the remainder of the experiment, the amount of onshore wind hours differed substantially. Of the 30 windy $\left(>5 \mathrm{~m} \mathrm{~s}^{-1}\right)$ hours during the onshore wind event,
25 were in the onshore direction, whereas only 1 of 54 windy hours in the offshore wind period was onshore. The prevailing wind direction during the onshore wind event was $305^{\circ}$, and during the offshore wind periods it was $180^{\circ}$.

DOBIE wave pressure measurements were used to calculate water depth, significant wave height and orbital bed velocity (Table 2). Larger wave heights defined onshore wind conditions from 10 to 12 December and resulted in the higher orbital bedload velocities $\left(U_{\mathrm{b}}\right)$ recorded at all sandflat sites compared to those recorded in offshore wind periods (Table 2). The interaction between the large waves and the shallower depth at US1 and US2 resulted in higher wave energy reaching the seabed $\left(U_{\mathrm{b}}{ }^{3}\right)$ compared to that at LS1, LS2 and $\mathrm{Ch}$ (Table 2). The DOBIE device in the tidal creek (Mu) showed no evidence of wave propagation up the creek, even during the December onshore wind event (Table 2). OBS measurements indicated higher concentrations of suspended sediment on incoming and outgoing tides than during slack tides at all sites during onshore wind conditions, but at only the tidal creek $(\mathrm{Mu})$ site during offshore wind conditions (data not shown).

ADVs measured current speed and direction during the December and February sampling periods at the US1 and Ch sites. The ADV at the Ch site experienced technological malfunctions during the December deployment such that only the first $24 \mathrm{~h}$ were sampled. Tidal currents were flood dominated at the $\mathrm{Ch}$ site, while the US1 site showed similar mean and maximum flows during incoming and outgoing tides (Table 3). Both sites showed bimodal distributions in current speed, peaking during incoming and outgoing tides, with a slack intermediate period.

\section{Temporal and spatial differences in the potential colonist pool}

Our data supported our first prediction that exposed sites (open sandflats) would have larger rates of coloni-

Table 1. Grain size distribution (\%), organic content (\%) and chlorophyll composition ( $\mathrm{mg} \mathrm{g}^{-1}$ sediment) of the surficial (top $2 \mathrm{~cm}$ ) sediment. Mean (SE) of both sampling periods for each of the 7 sites (see Fig. 1 for abbreviations)

\begin{tabular}{|lrrrrrrr}
\hline & US1 & \multicolumn{1}{c}{ US2 } & \multicolumn{1}{c}{ Ch } & \multicolumn{1}{c|}{ LS1 } & \multicolumn{1}{l}{ LS2 } & Mu \\
\hline Clay $(0$ to $3.9 \mu \mathrm{m})$ & $0.52(0.20)$ & $0.16(0.04)$ & $0.34(0.14)$ & $1.21(0.42)$ & $1.34(1.45)$ & $11.57(0.02)$ & $5.87(4.07)$ \\
Silt $(3.9$ to $62.5 \mu \mathrm{m})$ & $0.63(0.04)$ & $1.93(1.87)$ & $2.80(0.47)$ & $1.00(0.13)$ & $0.64(0.31)$ & $39.32(0.11)$ & $21.81(3.21)$ \\
Fine sand $(62.5$ to $250 \mu \mathrm{m})$ & $84.26(0.92)$ & $80.79(5.37)$ & $86.85(2.01)$ & $90.74(0.40)$ & $95.24(0.92)$ & $48.04(0.39)$ & $59.70(0.53)$ \\
Medium sand $(250$ to $500 \mu \mathrm{m})$ & $5.05(0.83)$ & $12.07(3.02)$ & $2.37(0.23)$ & $5.59(1.50)$ & $2.57(0.52)$ & $0.94(0.26)$ & $8.19(1.61)$ \\
Coarse sand $(500$ to $2000 \mu \mathrm{m})$ & $0.83(0.33)$ & $1.28(0.52)$ & $1.53(0.38)$ & $0.33(0.07)$ & $0.01(0.01)$ & $0.10(0.01)$ & $2.20(0.27)$ \\
Gravel (<2000 $\mu \mathrm{m})$ & $8.70(0.67)$ & $3.77(0.08)$ & $6.10(2.49)$ & $1.12(1.43)$ & $0.23(0.33)$ & $0.02(0.03)$ & $2.22(1.55)$ \\
Organic content & $0.66(0.12)$ & $0.61(0.15)$ & $1.07(0.37)$ & $0.63(0.04)$ & $0.61(0.06)$ & $5.56(0.37)$ & $2.19(0.11)$ \\
Chlorophyll a & $4.59(0.28)$ & $7.16(0.28)$ & $7.31(0.57)$ & $5.41(0.70)$ & $4.81(0.47)$ & $11.10(5.44)$ & $8.32(0.38)$ \\
\hline
\end{tabular}


Table 2. Physical climate from DOBIE measurements at experimental sites during the onshore wind event (10 to 12 December 2001) and the offshore wind period (12 to 14 December 2001 and 12 to 15 February 2002). Processing errors resulted in no data (n.d.) available for LS2 in December

\begin{tabular}{|c|c|c|c|c|c|c|c|}
\hline & Units & US1 & US2 & $\mathrm{Ch}$ & LS1 & LS2 & $\mathrm{Mu}$ \\
\hline \multicolumn{8}{|l|}{ Onshore winds } \\
\hline \multirow[t]{3}{*}{ Average wave } & Height (cm) & 9.36 & 11 & 5.88 & 8.56 & n.d. & 0.00 \\
\hline & Period (s) & 2.64 & 2.77 & 2.49 & 2.72 & n.d. & 0.00 \\
\hline & $U_{\mathrm{b}}^{3}\left(\mathrm{~cm}^{3} \mathrm{~s}^{-3}\right)$ & 18.2 & 20.42 & 6.69 & 9.17 & n.d. & 0.00 \\
\hline \multirow[t]{3}{*}{ Maximum wave } & Height (cm) & 23.48 & 25.68 & 19.23 & 25.55 & n.d. & 0.00 \\
\hline & Period (s) & 3.35 & 3.51 & 3.75 & 3.39 & n.d. & 0.00 \\
\hline & $U_{\mathrm{b}}^{3}\left(\mathrm{~cm}^{3} \mathrm{~s}^{-3}\right)$ & 34.99 & 37.37 & 22.51 & 20.48 & n.d. & 0.00 \\
\hline Maximum depth & $(\mathrm{m})$ & 0.85 & 0.98 & 1.85 & 2.00 & n.d. & 2.05 \\
\hline \multicolumn{8}{|l|}{ Offshore winds ${ }^{a}$} \\
\hline \multirow[t]{3}{*}{ Average wave } & Height (cm) & 0.61 & 0.43 & 0.28 & 0.29 & 0.04 & 0.00 \\
\hline & Period (s) & 2.13 & 0.88 & 0.35 & 0.23 & 0.09 & 0.00 \\
\hline & $U_{\mathrm{b}}^{3}\left(\mathrm{~cm}^{3} \mathrm{~s}^{-3}\right)$ & 1.50 & 1.03 & 0.50 & 0.48 & 0.05 & 0.00 \\
\hline \multirow[t]{3}{*}{ Maximum wave } & Height (cm) & 7.28 & 6.30 & 8.88 & 4.66 & 5.74 & 0.00 \\
\hline & Period (s) & 5.56 & 8.44 & 11.11 & 13.34 & 5.18 & 0.00 \\
\hline & $U_{\mathrm{b}}^{3}\left(\mathrm{~cm}^{3} \mathrm{~s}^{-3}\right)$ & 19.75 & 28.83 & 24.27 & 20.65 & 4.89 & 0.00 \\
\hline Maximum depth & $(\mathrm{m})$ & 0.77 & 0.87 & 1.79 & 1.94 & 2.07 & $1.03^{\mathrm{b}}$ \\
\hline \multicolumn{8}{|c|}{$\begin{array}{l}\text { aFor US1 and LS2, spurious data values at low water levels were discarded for } \\
\text { calculations }\end{array}$} \\
\hline \multicolumn{8}{|c|}{${ }^{\mathrm{b}}$ The tidal creek DOBIE was located approximately $200 \mathrm{~m}$ from the $\mathrm{Mu}$ site in } \\
\hline
\end{tabular}

sation compared to sheltered sites (tidal creeks) and that colonist pools within sites would differ temporally based on exposure to wind-waves and resulting higher energy transferred to the seabed. The number of animals collected in the sediment traps showed clear spatial differences in the pool of colonists within the estuary. While the sediment traps were sampled during times when larvae of benthic organisms were present in the water column (see e.g. Booth 1983, Roper et al. 1992), most organisms collected in traps were post-settlement juveniles (bivalves, polychaetes) or adults (gastropods, some polychaetes, amphipods,

Table 3. Mean current speed and direction from ADV instruments at the upper sandflat and channel sites during the December and February deployments

\begin{tabular}{|c|c|c|c|c|}
\hline & \multicolumn{2}{|c|}{ US1 } & \multicolumn{2}{|c|}{$\mathrm{Ch}$} \\
\hline & $\begin{array}{c}\text { Dec } \\
2001\end{array}$ & $\begin{array}{l}\text { Feb } \\
2002\end{array}$ & $\begin{array}{c}\text { Dec } \\
2001\end{array}$ & $\begin{array}{l}\text { Feb } \\
2002\end{array}$ \\
\hline \multicolumn{5}{|l|}{ Incoming tide } \\
\hline Maximum current speed $\left(\mathrm{cm} \mathrm{s}^{-1}\right)$ & 16.40 & 18.05 & 32.85 & 30.07 \\
\hline Mean current speed $\left(\mathrm{cm} \mathrm{s}^{-1}\right)$ & 9.31 & 10.51 & 19.18 & 17.07 \\
\hline Median direction (deg) & 315 & 315 & 0 & 305 \\
\hline \multicolumn{5}{|l|}{ Outgoing tide } \\
\hline Maximum current speed $\left(\mathrm{cm} \mathrm{s}^{-1}\right)$ & 23.44 & 20.43 & 21.97 & 21.88 \\
\hline Mean current speed $\left(\mathrm{cm} \mathrm{s}^{-1}\right)$ & 8.71 & 9.59 & 13.52 & 12.25 \\
\hline Median direction (deg) & 135 & 140 & 180 & 110 \\
\hline
\end{tabular}

decapods), with the few larvae collected consisting of crab megalopae and barnacle cyprids. The traps at the $\mathrm{Ch}, \mathrm{Mu}$ and $\mathrm{Ma}$ sites collected consistently lower numbers of animals than those at the upper and lower sandflat sites, though there was still a significant increase during the onshore wind event (Fig. 2, Table 4, Appendix 1). During the onshore wind event, 5 to 10 times more macrofaunal individuals were collected in the bedload traps at all the sandflat sites than during the offshore wind period (Fig. 2, Table 4, Appendix 1). The number of macrofaunal taxa showed similar patterns, with 2 to 5 times higher species richness at the sandflat sites during the onshore wind event than during the offshore wind period (Fig. 3, Table 4, Appendix 1). Differences between onshore and offshore wind periods were significant, though smaller in magnitude at the Mu and Ma sites (Fig. 3, Table 4).

Bedload traps at sandflat sites generally collected higher numbers of macrofaunal individuals than water column traps (Fig. 2). A similar relationship with trap height was observed for macrofaunal taxa and sediment weight collected in the sediment traps at most sandflat sites (Figs. 3 \& 4). Trap height differences were less clear at tidal creek sites (Figs. 2 to 4). Sediment grain size analysis showed that sediment traps generally reflected sediment composition in ambient sediments at each site (data not shown). The proportion of silt/clay in the sediment traps increased with trap height, and was larger during offshore wind periods than during the onshore wind event. Differences in sediment composition between trap collections and ambient sediments were most noticeable at 3 of the sandflat sites (Ch, LS1, LS2), with up to $30 \%$ greater proportions of silt/clay particles in traps compared to ambient sediment cores. Smaller differences in particle size distributions between traps and cores were observed at US1 and US2 (with generally low proportions of silt/clay particles in all samples) and at $\mathrm{Mu}$ and Ma (with generally high proportions of silt/clay particles in all samples). 


\section{Role of environmental variables in influencing colonisation}

Predictions of the influence of wind-waves on the colonist pool were further supported by multiple regression models of the physical variables on trap macrofauna. We analysed the ratio of macrofaunal individuals in traps compared to ambient cores at each of the 3 trap heights. These regressions revealed that environmental variables explained decreasing amounts of the variability $(72,59$ and $48 \%$ for bedload, $5 \mathrm{~cm}$ and $15 \mathrm{~cm}$ traps, respectively) as trap height increased (Table 5). Physical variables representing wind-wave activity and sediment resuspension (maximum wave height, maximum and average bedload velocities, maximum windspeed, maximum and average OBS) were significant in some combination for all trap heights. Maximum depth (correlated with inundation time) was significant for all trap heights, likely representing exposure time for colonisation. Variables associated with the local wave environment (sediment weight collected in traps, model: habitat) were strong predictors for bedload traps, linking passive transport of sediment with presence of macrofauna in the colonist pool. In contrast, variables associated with larger scale dispersal (model: disperse and model: far) were significant predictors at 5 or $15 \mathrm{~cm}$ trap heights, indicating different processes were responsible for organisms avail-

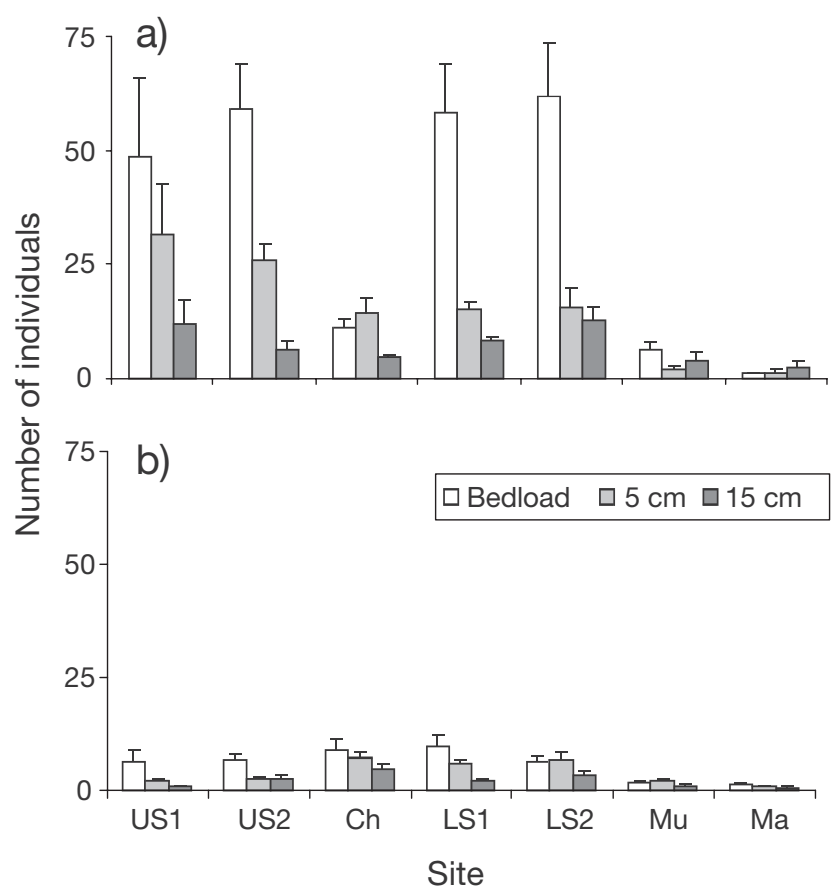

Fig. 2. Average number of macrofaunal individuals collected at the 3 trap heights (bedload, $5 \mathrm{~cm}$ and $15 \mathrm{~cm}$ ) at the 7 sites during: (a) the December onshore wind event and (b) the offshore wind period in December and February. Values are averages of daily trap counts for each trap height during each period $(+\mathrm{SE})$

Table 4. Results of analysis of variance on the effect of site and weather on the number of macrofauna, number of taxa, sediment weight collected in sediment traps at 3 different heights and ratio of ambient (core) to trap macrofauna. Where a significant weather $\times$ site interaction $(p<0.15)$ was reported, $p$-values for the effect of site on each weather type are given. Values in bold are significant at $\mathrm{p}<0.05$. Results of Bonferroni post hoc comparisons are given in Appendix 1

\begin{tabular}{|c|c|c|c|c|c|c|}
\hline Factor & df & Sum of squares & $F$-ratio & p-value & Weather & $\begin{array}{c}\text { Treatment } \\
\text { p-value }\end{array}$ \\
\hline \multicolumn{7}{|c|}{ Number of macrofaunal individuals } \\
\hline Model & 13 & 1406675.96 & 16.28 & $<0.0001$ & Offshore & $<0.0001$ \\
\hline Error & 130 & 877607.02 & & & Onshore & $<0.0001$ \\
\hline Weather & 1 & 406911.32 & 61.20 & $<0.0001$ & & \\
\hline Site & 6 & 906334.00 & 22.72 & $<0.0001$ & & \\
\hline Weather $\times$ Site & 6 & 117558.85 & 2.95 & 0.0099 & & \\
\hline \multicolumn{7}{|l|}{$5 \mathrm{~cm}$ traps } \\
\hline Model & 13 & 1432841.60 & 24.70 & $<0.0001$ & Offshore & $<0.0001$ \\
\hline Error & 130 & 593413.23 & & & Onshore & $<0.0001$ \\
\hline Weather & 1 & 346810.37 & 77.73 & $<0.0001$ & & \\
\hline Site & 6 & 833657.26 & 31.14 & $<0.0001$ & & \\
\hline Weather $\times$ Site & 6 & 223884.73 & 8.36 & $<0.0001$ & & \\
\hline \multicolumn{7}{|l|}{$15 \mathrm{~cm}$ traps } \\
\hline Model & 13 & 957451.57 & 9.53 & $<0.0001$ & & \\
\hline Error & 130 & 1004605.77 & & & & \\
\hline Weather & 1 & 415969.17 & 53.83 & $<0.0001$ & & \\
\hline Site & 6 & 401839.35 & 8.67 & $<0.0001$ & & \\
\hline Weather $\times$ Site & 6 & 72566.17 & 1.57 & 0.1624 & & \\
\hline
\end{tabular}

(Table continued on next page) 
Table 4 (continued)

\begin{tabular}{|c|c|c|c|c|c|c|}
\hline Factor & df & Sum of squares & $F$-ratio & $\mathrm{p}$-value & Weather & $\begin{array}{c}\text { Treatmen } \\
\text { p-value }\end{array}$ \\
\hline \multicolumn{7}{|c|}{ Number of macrofaunal taxa } \\
\hline \multicolumn{7}{|c|}{ Bedload traps } \\
\hline Model & 13 & 1175556.54 & 11.42 & $<0.0001$ & Offshore & $<0.0001$ \\
\hline Error & 130 & 1045512.58 & & & Onshore & $<0.0001$ \\
\hline Weather & 1 & 379481.67 & 47.91 & $<0.0001$ & & \\
\hline Site & 6 & 710296.14 & 14.95 & $<0.0001$ & & \\
\hline Weather $\times$ Site & 6 & 133286.93 & 2.80 & 0.0134 & & \\
\hline \multicolumn{7}{|l|}{$5 \mathrm{~cm}$ traps } \\
\hline Model & 13 & 1252544.68 & 16.63 & $<0.0001$ & Offshore & $<0.0001$ \\
\hline Error & 130 & 770744.83 & & & Onshore & $<0.0001$ \\
\hline Weather & 1 & 430681.01 & 74.32 & $<0.0001$ & & \\
\hline Site & 6 & 656359.20 & 18.88 & $<0.0001$ & & \\
\hline Weather $\times$ Site & 6 & 201079.00 & 5.78 & $<0.0001$ & & \\
\hline \multicolumn{7}{|l|}{$15 \mathrm{~cm}$ traps } \\
\hline Model & 13 & 1060436.77 & 10.98 & $<0.0001$ & & \\
\hline Error & 130 & 965943.98 & & & & \\
\hline Weather & 1 & 511279.00 & 68.81 & $<0.0001$ & & \\
\hline Site & 6 & 455000.74 & 10.21 & $<0.0001$ & & \\
\hline Weather $\times$ Site & 6 & 27479.60 & 0.62 & 0.7169 & & \\
\hline \multicolumn{7}{|c|}{ Sediment weight } \\
\hline \multicolumn{7}{|c|}{ Bedload traps } \\
\hline Model & 13 & 1040055.95 & 9.69 & $<0.0001$ & & \\
\hline Error & 130 & 1090202.74 & & & & \\
\hline Weather & 1 & 304121.83 & 36.82 & $<0.0001$ & & \\
\hline Site & 6 & 658341.23 & 13.29 & $<0.0001$ & & \\
\hline Weather $\times$ Site & 6 & 55094.94 & 1.11 & 0.3589 & & \\
\hline \multicolumn{7}{|l|}{$5 \mathrm{~cm}$ traps } \\
\hline Model & 13 & 925155.68 & 7.12 & $<0.0001$ & & \\
\hline Error & 130 & 770744.83 & & & & \\
\hline Weather & 1 & 509901.28 & 50.99 & $<0.0001$ & & \\
\hline Site & 6 & 389878.59 & 6.50 & $<0.0001$ & & \\
\hline Weather $\times$ Site & 6 & 100993.98 & 1.68 & 0.1298 & & \\
\hline \multicolumn{7}{|l|}{$15 \mathrm{~cm}$ traps } \\
\hline Model & 13 & 573446.52 & 5.75 & $<0.0001$ & Offshore & 0.3548 \\
\hline Error & 130 & 997695.98 & & & Onshore & 0.0002 \\
\hline Weather & 1 & 281470.32 & 36.68 & $<0.0001$ & & \\
\hline Site & 6 & 236658.81 & 5.14 & $<0.0001$ & & \\
\hline Weather $\times$ Site & 6 & 115607.74 & 2.51 & 0.0248 & & \\
\hline \multicolumn{7}{|c|}{ Ratio of number of macrofauna in traps to ambient cores } \\
\hline \multicolumn{7}{|c|}{ Bedload traps } \\
\hline Model & 13 & 1437611.32 & 18.9 & $<0.0001$ & Offshore & $<0.0001$ \\
\hline Error & 132 & 772200.07 & & & Onshore & $<0.0001$ \\
\hline Site & 6 & 1115622.17 & 31.78 & $<0.0001$ & & \\
\hline Weather & 1 & 213672.51 & 36.53 & $<0.0001$ & & \\
\hline Site $\times$ Weather & 6 & 98089.83 & 2.79 & 0.0136 & & \\
\hline \multicolumn{7}{|l|}{$5 \mathrm{~cm}$ traps } \\
\hline Model & 13 & 1247776.03 & 17.84 & $<0.0001$ & Offshore & $<0.0001$ \\
\hline Error & 133 & 715726.33 & & & Onshore & $<0.0001$ \\
\hline Site & 6 & 865768.72 & 26.81 & $<0.0001$ & & \\
\hline Weather & 1 & 226337.31 & 42.06 & $<0.0001$ & & \\
\hline Site $\times$ Weather & 6 & 169213.18 & 5.24 & $<0.0001$ & & \\
\hline \multicolumn{7}{|l|}{$15 \mathrm{~cm}$ traps } \\
\hline Model & 13 & 1016086.49 & 9.41 & $<0.0001$ & Offshore & $<0.0001$ \\
\hline Error & 133 & 1080011.30 & & & Onshore & $<0.0001$ \\
\hline Site & 6 & 562493.33 & 11.28 & $<0.0001$ & & \\
\hline Weather & 1 & 292222.89 & 35.17 & $<0.0001$ & & \\
\hline Site $\times$ Weather & 6 & 104670.04 & 2.10 & 0.0575 & & \\
\hline
\end{tabular}




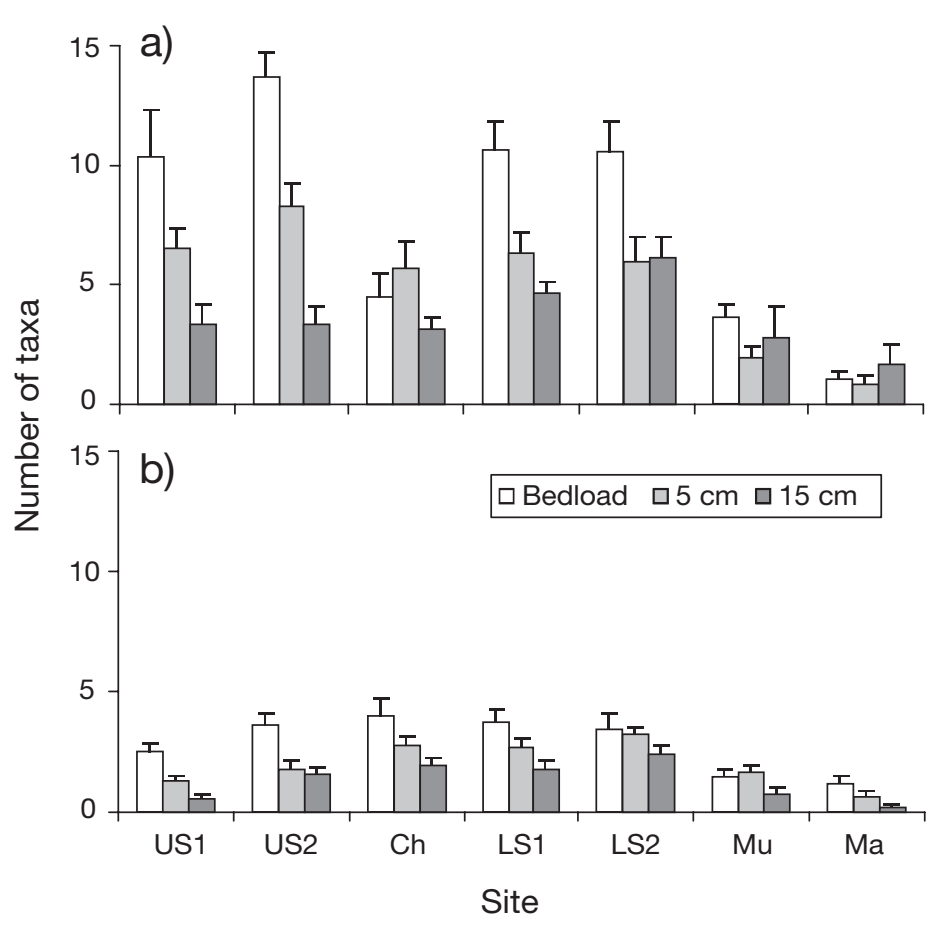

Fig. 3. Average number of macrofaunal taxa collected at the 3 trap heights (bedload, $5 \mathrm{~cm}$ and $15 \mathrm{~cm}$ ) at the 7 sites during: (a) the December onshore wind event and (b) the offshore wind period in December and February. Values are averages of daily trap counts for each trap height during each period $( \pm 1 \mathrm{SE})$

able in the colonist pool above the sediment surface. The large proportion of the variance explained by variables representing wind-wave activity implied that windwaves are a major influence on organism transport.

\section{Comparison of colonising macrofauna with ambient community}

Our results supported predictions that the influence of ambient communities on colonisation rates differed with respect to physical conditions experienced by each site. Analysis of variance of the ratio of sediment trap macrofauna to ambient fauna in cores illustrated significant differences between sites and with weather conditions for all 3 trap heights (Table 4). Species composition varied between location and between ambient cores and sediment trap collections (Fig. 5), though most species were found at all ambient sites in varying abundance. Macrofauna were represented by the major taxonomic groups: bivalves, polychaetes, amphipods and others, which included primarily crabs, gastropods, cumaceans and isopods. Ambient communities were dominated by deposit-feeding polychaetes (Aonides oxycephala, Aricidea sp., Aquilaspio auck- landica, Heteromastus filiformis, Macroclymenella stewartensis; 41 to $92 \%$ of total individuals) at all sites except the Ch site, which had a high percent composition of bivalves $(61 \%)$, composed primarily of the suspension-feeder Austrovenus stutchburyi and the deposit-feeder Nucula hartvigiana (Fig. 5a). The tidal creek sites had higher percentages of polychaetes than did the sandflat sites, with 92 and $71 \%$ polychaetes, respectively, at the $\mathrm{Mu}$ and $\mathrm{Ma}$ sites. Crabs (Helice crassa, Macropthalmus hirtipes, Hemigrapsus edwardsi), primarily detritivores, were also more abundant at tidal creek sites.

Our results supported predictions of differences in colonisation strategies, as we found differences in the availability of colonists relative to their abundance in the ambient sediments (Fig. 5). Trap samples also supported predictions of recruitment limitation at all sites, in that colonisation was primarily by post-settlement juveniles and adults, rather than larvae, at all sites. In contrast to ambient core samples, amphipods and bivalves generally formed more than half of the total individuals in the sediment trap samples in both onshore and offshore wind conditions (Fig. 5b,c). Amphipods collected in sediment traps were generally adults, while bivalves were represented by post-settlement juveniles $(<5 \mathrm{~mm})$. Juvenile bivalves were collected in water column traps during onshore and offshore wind periods, indicating an active behavioural role to promote transport during conditions without wind-waves. Bivalves formed a larger proportion of total individuals during the onshore wind event ( 7 to $66 \%$ ) than during offshore wind periods (5 to $23 \%$ ) (Fig. 5b,c). Polychaetes in traps included both juveniles and adult swimming species. No consistent differences in taxonomic composition were observed with trap height across locations, as many organisms that were suspected of water column transport were also collected in bedload traps.

Multivariate plots of macrofaunal community composition in sediment traps and ambient cores showed a distinct divergence between colonising macrofauna collected in traps and ambient communities in cores, with similar results for both raw and square-root-transformed data implying that species differences, rather than variation in abundance, were driving community differences between sites (raw data analysis shown in Fig. 6). The plot also illustrates similarity between trap macrofaunal composition during offshore wind conditions at all sites and tidal creek sites during the onshore wind event, while the sandflat sites during the onshore wind event are in a distinct cluster. Some differentiation by trap height is also evident for sandflat sites during both the onshore and offshore wind periods, with bedload traps being most similar in ordination space to ambient cores. 


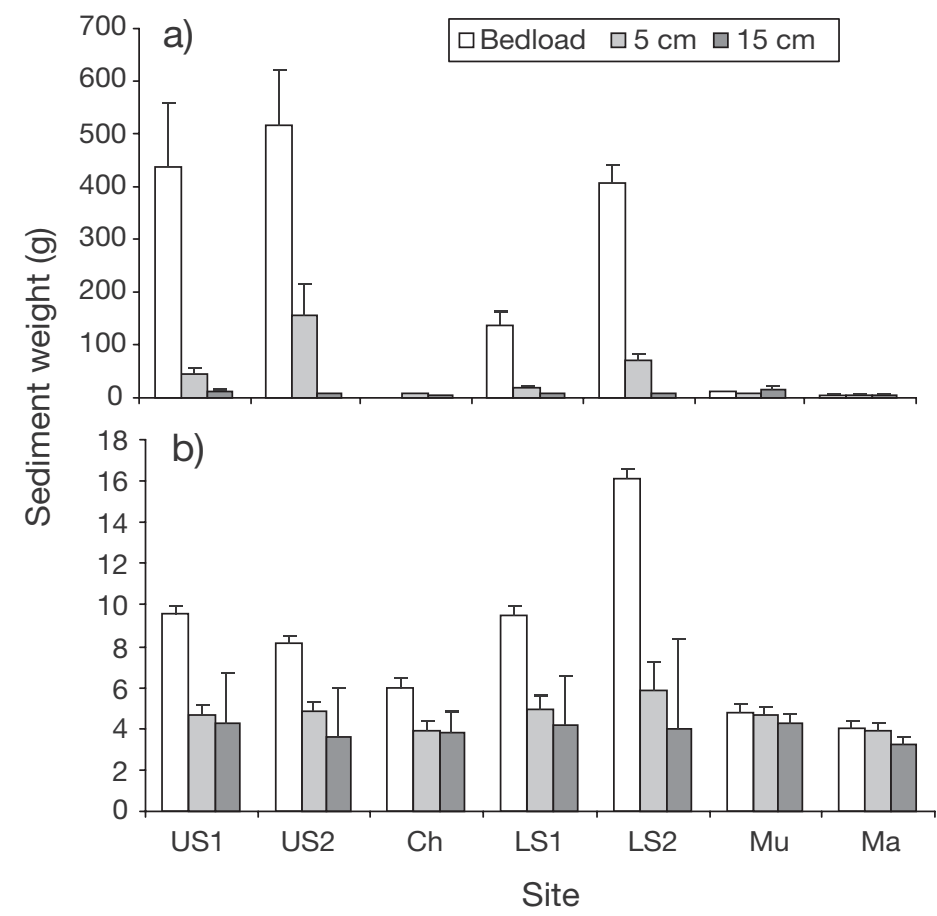

Fig. 4. Average sediment weight collected at the 3 trap heights (bedload, $5 \mathrm{~cm}$ and $15 \mathrm{~cm}$ ) at the 7 sites during: (a) the December onshore wind event and (b) the offshore wind period in December and February. Values are averages of sediment weights for each trap height during each period (+SE). Note different scales

\section{DISCUSSION}

Our results illustrate spatial and temporal differences in the number and diversity of the potential pool of colonists available for recovery from disturbance in estuaries. Key drivers of spatial variability were physical differences between sites that affect exposure and inundation time, while temporal variability was influenced primarily by weather conditions that promoted transport of macrofauna. Wind-waves were a major factor influencing the pool of colonists available for recolonisation of disturbed intertidal soft-sediment areas. Tidal currents and ambient communities had relatively minor impacts on variability in the pool of available colonists.

\section{Influence of wind-wave disturbance on organism transport}

Our results illustrate the strong role of wind-waves in transporting organisms in shallow, soft-sediment systems. Site-related differences in hydrodynamics and exposure to wind-generated waves were key factors influencing variability in colonist pools
Table 5. Multiple regression analysis of the abundance of macrofauna collected in sediment traps at 3 trap heights (OBS: optical back-scatter; SS: sum of squares)

\begin{tabular}{|c|c|c|c|c|}
\hline \multicolumn{5}{|c|}{ Bedload traps $\left(r^{2}=0.7206\right)$} \\
\hline \multicolumn{3}{|c|}{$\begin{array}{lll}\text { Source } & \text { df }\end{array}$} & $F$ & $\operatorname{Pr}>F$ \\
\hline Model & 7 & 28.42474 & 39.79 & $<0.0001$ \\
\hline Error & 108 & 11.02059 & & \\
\hline Variable & $\mathrm{df}$ & $\begin{array}{l}\text { Parameter } \\
\text { estimate }\end{array}$ & $t$ & $\operatorname{Pr}>|t|$ \\
\hline Intercept & 1 & 0.02476 & 0.13 & 0.8962 \\
\hline Sediment weight & 1 & 0.00266 & 10.36 & $<0.0001$ \\
\hline Model habitat & 1 & 0.00869 & 4.28 & $<0.0001$ \\
\hline Max. depth & 1 & -0.17685 & -2.52 & 0.0134 \\
\hline Max. wave & 1 & 0.03423 & 3.37 & 0.0011 \\
\hline Max. bed velocity & 1 & -0.02090 & -3.01 & 0.0033 \\
\hline Max. OBS & 1 & 0.57832 & 2.71 & 0.0079 \\
\hline Avg. OBS & 1 & -2.50788 & -3.14 & 0.0022 \\
\hline \multicolumn{5}{|c|}{$5 \mathrm{~cm}$ traps $\left(\mathrm{r}^{2}=0.5884\right)$} \\
\hline Source & $\mathrm{df}$ & SS & $F$ & $\operatorname{Pr}>F$ \\
\hline Model & 6 & 8.24301 & 26.21 & $<0.0001$ \\
\hline Error & 110 & 5.76636 & & \\
\hline Variable & df & $\begin{array}{l}\text { Parameter } \\
\text { estimate }\end{array}$ & $t$ & $\operatorname{Pr}>|t|$ \\
\hline Intercept & 1 & -0.88924 & -3.93 & 0.0001 \\
\hline Model: disperse & 1 & 0.02102 & 5.30 & $<0.0001$ \\
\hline Model: far & 1 & -0.02193 & -6.09 & $<0.0001$ \\
\hline Max. depth & 1 & 0.25545 & 4.25 & $<0.0001$ \\
\hline Avg. bed velocity & 1 & 0.05717 & 8.19 & $<0.0001$ \\
\hline Max. bed velocity & 1 & -0.01221 & -3.31 & 0.0013 \\
\hline Max. OBS & 1 & 0.63897 & 3.78 & 0.0003 \\
\hline \multicolumn{5}{|c|}{$15 \mathrm{~cm}$ traps $\left(\mathrm{r}^{2}=0.4767\right)$} \\
\hline Source & df & SS & $F$ & $\operatorname{Pr}>F$ \\
\hline Model & 7 & 1.15646 & 13.79 & $<0.0001$ \\
\hline Error & 106 & 1.26972 & & \\
\hline Variable & df & $\begin{array}{l}\text { Parameter } \\
\text { estimate }\end{array}$ & $t$-value & $\operatorname{Pr}>|t|$ \\
\hline Intercept & 1 & -0.19262 & -1.53 & 0.1280 \\
\hline Model: disperse & 1 & 0.00692 & 3.62 & 0.0005 \\
\hline Model: far & 1 & -0.00735 & -4.20 & $<0.0001$ \\
\hline Max. depth & 1 & 0.11907 & 3.82 & 0.0002 \\
\hline Max. wind & 1 & -0.01928 & -3.14 & 0.0022 \\
\hline Max. wave & 1 & -0.00773 & -2.20 & 0.0299 \\
\hline Avg. bed velocity & 1 & 0.02350 & 5.10 & $<0.0001$ \\
\hline Max. OBS & 1 & 0.32624 & 4.03 & 0.0001 \\
\hline
\end{tabular}

between sites. Sheltered tidal creek sites had lower rates of colonisation than more exposed sandflat sites. Higher rates of colonisation of disturbed plots have been shown during wind- and storm-related events, and when comparing between sheltered and exposed locations (Zajac \& Whitlatch 1982a, Norkko et al. 2002, Hewitt et al. 2003), though it is important to note the 


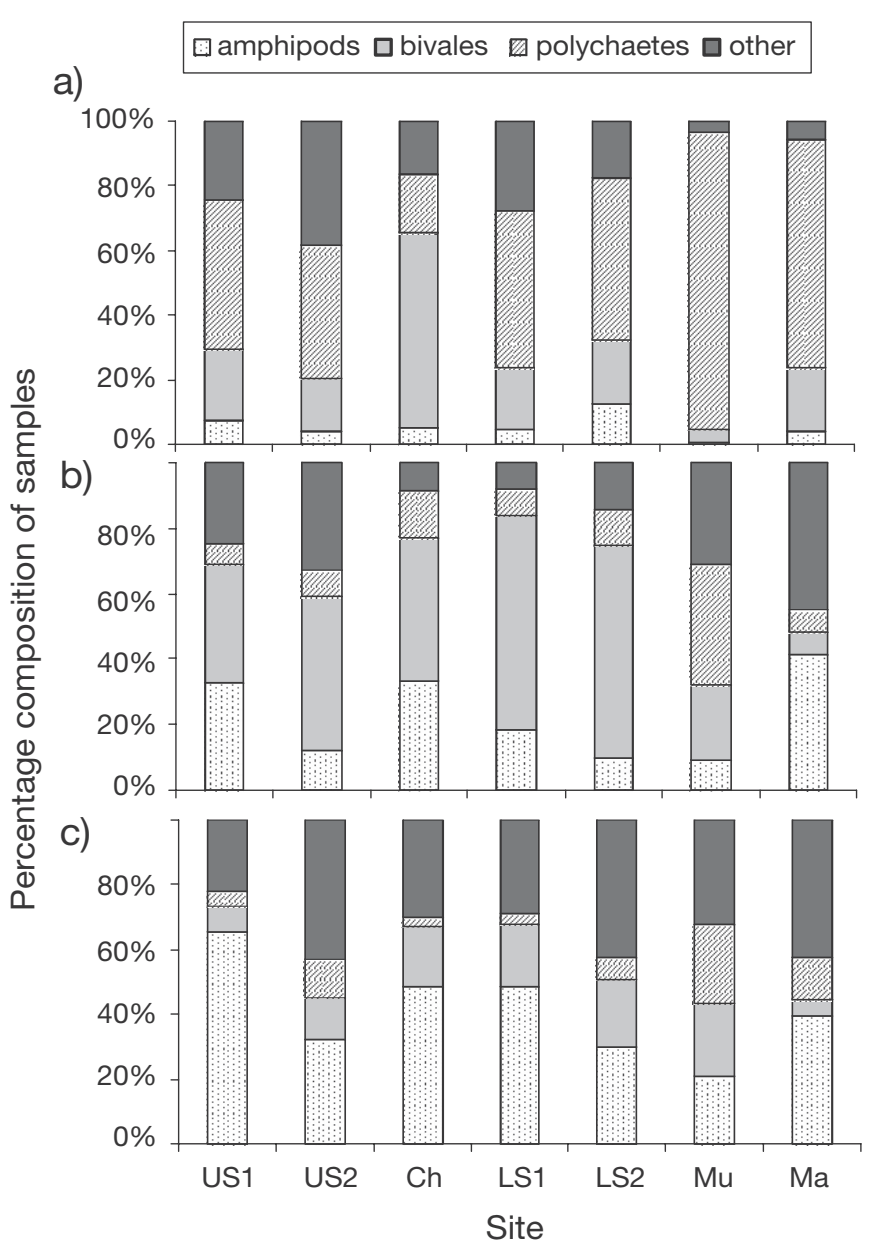

Fig. 5. Taxon composition of macrofauna found in the ambient cores and the sediment traps. Trap counts were averaged over all trap heights (bedload, $5 \mathrm{~cm}$ and $15 \mathrm{~cm}$ ). Percent composition by taxa in: (a) ambient cores, (b) sediment traps during onshore wind event and (c) sediment traps during offshore wind period generally slow recovery of New Zealand soft-sediment communities after disturbance (Thrush et al. 1996, 2003). Abundance of organisms in traps increased for both bedload and water column traps, suggesting increased rates of passive bedload transport as well as resuspension to greater heights in the water column with wave activity. In contrast, tidal currents rarely exceed the threshold for sediment resuspension on New Zealand estuarine sandflats (Bell et al. 1997, Green et al. 1997), indicating that a combination of both tides and waves is required to result in high transport rates of both sediments and macrofauna (Dolphin et al. 1995, Hewitt et al. 1997). Strong tidal currents, while not resulting in resuspension, can have additional effects on colonist availability, as predicted by hydrodynamic models, as fewer organisms are available for settling due to high flow rates at the sediment surface limiting settling behaviour (Abelson \& Denny 1997, Lundquist et al. 2004b). We did observe a logarithmic profile of sediment weight with increasing trap height at some sites during the onshore wind period, potentially related to a theoretical relationship of increasing flow velocity with height due to boundary layer impacts (Vogel 1994); however, this logarithmic profile was not evident during calm conditions for sediment weight, or at sites without wind-waves, suggesting that turbulent dynamics rather than velocity profiles were responsible for differences in abundance with respect to trap heights.

\section{Role of macrofaunal life history in recovery potential}

While we did not observe consistent differences with trap height across the 7 sampling locations, clear differences in species composition were apparent

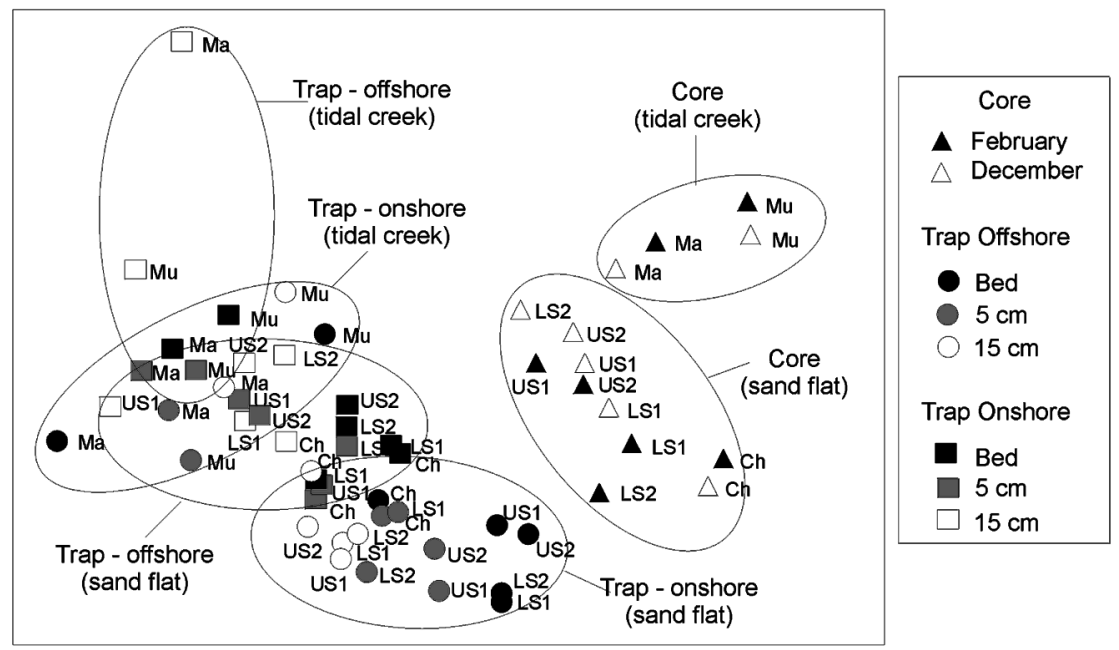

Fig. 6. Multi-dimensional scaling analysis of raw data showing differences between macrofaunal assemblages collected in sediment traps and in ambient sediments. Triangles represent average of macrofaunal cores at each site collected during the December (black) and February (white) sampling period. Squares represent average of macrofauna in sediment traps during the offshore wind period, while circles represent average of macrofauna in sediment traps during the onshore wind event. Shading of squares and circles signifies trap height: bedload (black), $5 \mathrm{~cm}$ (grey) and $15 \mathrm{~cm}$ (white). Encircled areas enclose core and trap samples from tidal creek and sandflat sites, and trap samples at tidal creek and sandflat sites during onshore and offshore wind conditions 
between onshore and offshore wind conditions. We observed active adult dispersers, including amphipods and errant polychaetes and other swimming and crawling species, such as crabs, gastropods and cumaceans, during offshore wind periods, while collections during onshore wind periods were dominated by bivalves. Transport of juvenile bivalves is often correlated with passive sediment transport (Emerson \& Grant 1991, Commito et al. 1995a, 1995b, Shull 1997, Turner et al. 1997), though active behaviour has a clear role in influencing transport of bivalves through behaviours that both increase and decrease the likelihood of transport (Cummings et al. 1993, 1995, Shull 1997, Lundquist et al. 2004a). Active emergence behaviours, as well as byssal- or mucous-thread drifting, by post-settlement juvenile bivalves have been linked to transport at flows below that which is required for passive bedload transport (Cummings et al. 1993, Norkko et al. 2001, Lundquist et al. 2004a), which can explain the presence of juvenile bivalves in water column traps during offshore wind periods. In contrast, few sedentary tube-dwelling polychaetes were collected in sediment traps, supporting expectations of reduced transport through active behavioural mechanisms by these species (Thrush et al. 1991, Shull 1997).

Smaller numbers of animals collected in the water column versus bedload traps support other experimental studies of colonisation (Commito et al. 1995b, Cummings et al. 1995, Hewitt et al. 1997, Turner et al. 1997). As organisms found in the water column will be transported farther distances than those transported in the bedload (Lundquist et al. 2004a), our results suggest that most organisms are moved only short distances. As wind-waves increased the number of organisms collected in water column traps, our results suggest that storm-related transport is an important process for long-distance recolonisation of disturbed areas.

\section{Influence of ambient community on pool of colonists}

Hydrodynamic models predict that average distances travelled by broadly dispersing organisms in shallow estuaries are on the order of $100 \mathrm{~m} \mathrm{~d}^{-1}$ (Lundquist et al. 2004b), implying that colonist pools should be at least partially determined by the ambient community. While we were unable to determine the origin of any organisms collected in sediment traps, multivariate ordinations show separation between sites, most notably between tidal creek and exposed sandflat locations. We observed a higher amount of overlap in multivariate comparisons of species abundance and composition in the trap samples compared to the ambient samples, indicating the populations are less habitat sorted in the water column than in the sediment. Potentially, this reflects the stronger influence of a regional colonist pool than a local colonist pool on colonist abundance. This pattern in species composition could also reflect that dispersing fauna collected in traps are a limited subset of total macrofauna present in the sediment (e.g. low abundance of polychaetes relative to ambient sediment abundance), or that total abundance in traps was smaller than in ambient sediments, influencing our ability to resolve differences between sites. More importantly, differences in colonist abundance between locations and with differing hydrodynamic conditions were apparent, and clearly important in determining spatial and temporal rates of colonisation.

Available colonist pools have been examined using passive sediment traps and plankton nets, correlating relative abundance of available colonists with ambient community dynamics (Cummings et al. 1995, Hewitt et al. 1997). Passive trap measurements of settlement rates may be biased high, reflecting the inability of trapped organisms to leave an unsuitable substrate, compared to actual settlement behaviour. One study has demonstrated correlations between available colonists collected in sediment traps (water column and bedload) and abundance of recent colonists within local sediments (Turner et al. 1997). Clearly behavioural processes are important in the colonisation process in soft-sediment systems, in addition to colonist availability, as organisms can choose to settle based on numerous biological and environmental factors. Various studies have demonstrated both positive and negative correlations between colonising fauna and/or juvenile abundance and the presence of conspecifics and environmental variables such as the presence of shell hash (Hewitt et al. 1996, Turner et al. 1997). Even with relatively high rates of wind-induced transport of post-settlement juveniles, ambient communities show stability in spatial patterns of abundance (Hewitt et al. 1997).

The relative importance of different life-history stages of organisms with respect to recolonisation has also been observed to change with the size of the disturbed patch (Thrush et al. 1996, Zajac et al. 1998). Numerous studies have documented high rates of 'local' colonisation of disturbed plots, particularly through passive transport of post-settlement juveniles and adults (Thrush et al. 1996, Whitlatch et al. 1998). The prevalence of local transport may also explain experimental evidence of edge effects, and strong negative effects of increasing patch size on colonisation rates (Thrush et al. 1996, Zajac \& Whitlatch 2003). Seasonal availability of larval and juvenile colonists can also have a strong influence on the macrofauna colonising disturbed locations (Zajac \& Whitlatch 
1982b). Smaller disturbed patches may be more likely to be colonised via passive and active transport of organisms from adjacent sandflats (Thrush \& Whitlatch 2001). In contrast, larger patches are more dependent on these seasonal larval colonists with broadly dispersing planktonic larvae (Zajac \& Whitlatch 1982b, Thrush \& Whitlatch 2001).

\section{Implications for recovery potential in estuaries}

Our results indicate a clear role of hydrodynamic-biological interactions in transport and potential recovery rates in intertidal estuaries. In particular, we predict locations that are most sensitive to, and are least likely to recover from, disturbance due to relatively lower rates of colonisation. Spatial differences in colonisation potential suggest that communities at locations with low colonisation potential are less likely to persist when faced with increasing rates of disturbance. The influence of ambient communities on colonisation suggests that large disturbed areas may take much longer to recover than smaller, more localised disturbances, as most colonist transport is over small distances. Our results importantly validate the use of hydrodynamic models as surrogates for intensive field experiments to determine relative recovery rates at different locations within estuaries.

Acknowledgements. This research was funded by the New Zealand Foundation for Research Science and Technology, programmes Nos. C01X0024, C01X0307 and C01X0305. We thank K. Theobald, S. Hatton and P. Nicholls for assistance with field sampling and processing of samples. G. Funnell and D. Lohrer provided assistance with taxonomic identifications. Two anonymous reviewers provided helpful comments on the manuscript.

\section{LITERATURE CITED}

Abelson A, Denny M (1997) Settlement of marine organisms in flow. Annu Rev Ecol Syst 28:317-339

Bell RG, Hume TM, Dolphin TJ, Green MO, Walters RA (1997) Characterisation of physical environmental factors on an intertidal sandflat, Manukau Harbour, New Zealand. J Exp Mar Biol Ecol 216:11-31

Belsley DA, Kuh E, Welsch RE (1980) Regression diagnostics: identifying influential data and sources of colinearity. John Wiley \& Sons, New York

Beukema JJ, de Vlas J (1989) Tidal-current transport of thread-drifting postlarval juveniles of bivalve Macoma balthica from the Wadden Sea to the North Sea. Mar Ecol Prog Ser 52:193-200

Blanton JO, Werner FE, Kapolnai A, Blanton BO, Knott D, Wenner EL (1999) Wind-generated transport of fictitious passive larvae into shallow tidal estuaries. Fish Oceanogr 8:210-223

Booth JD (1983) Studies on twelve common bivalve larvae, with notes on bivalve spawning seasons in New Zealand. NZ J Mar Freshw Res 17:231-265
Clarke KR, Warwick RM (1994) Change in marine communities: an approach to statistical analysis and interpretation. Natural Environment Research Council, Plymouth

Commito JA, Currier CA, Kane LR, Reinsel KA, Ulm IM (1995a) Dispersal dynamics of the bivalve Gemma gemma in a patchy environment. Ecol Monogr 65:1-20

Commito JA, Thrush SF, Pridmore RD, Hewitt JE, Cummings VJ (1995b) Dispersal dynamics in a wind-driven benthic system. Limnol Oceanogr 40:1513-1518

Cummings VJ, Pridmore RD, Thrush SF, Hewitt JE (1993) Emergence and floating behaviours of post-settlement juveniles of Macomona liliana (Bivalvia: Tellinacea). Mar Behav Physiol 24:25-32

Cummings VJ, Pridmore RD, Thrush SF, Hewitt JE (1995) Post-settlement movement by intertidal benthic macroinvertebrates: Do common New Zealand species drift in the water column? NZ J Mar Freshw Res 29:59-67

Dolphin TJ, Hume TM, Parnell KE (1995) Oceanographic processes and sediment mixing on a sand flat in an enclosed sea, Manukau Harbour, New Zealand. Mar Geol 128:169-181

Ellien C, Thiebaut E, Barnay AS, Dauvin JC, Gentil F, Salomon JC (2000) The influence of variability in larval dispersal on the dynamics of a marine metapopulation in the eastern channel. Oceanol Acta 23:423-442

Ellis JI, Norkko A, Thrush SF (2000) Broad-scale disturbance of intertidal and shallow sublittoral soft-sediment habitat; effects on the benthic macrofauna. J Aquat Ecosyst Stress Recovery 7:57-74

Emerson CW, Grant J (1991) The control of soft-shell clam (Mya arenaria) recruitment on intertidal sandflats by bedload sediment transport. Limnol Oceanogr 36: 1288-1300

Grantham BA, Eckert GL, Shanks AL (2003) Dispersal potential of marine invertebrates in diverse habitats. Ecol Appl 13:S108-S116

Green MO, Black KP (1999) Suspended-sediment reference concentration under waves: field observations and critical analysis of two predictive models. Coast Eng 38:115-141

Green MO, Black KP, Amos CL (1997) Control of estuarine sediment dynamics by interactions between currents and waves at several scales. Mar Geol 144:97-116

Hewitt JE, Thrush SF, Cummings VJ, Pridmore RD (1996) Matching patterns with processes: predicting the effect of size and mobility on the spatial distributions of the bivalves Macomona liliana and Austrovenus stutchburyi. Mar Ecol Prog Ser 135:57-67

Hewitt JE, Pridmore RD, Thrush SF, Cummings VJ (1997) Assessing the short-term stability of spatial patterns of macrobenthos in a dynamic estuarine system. Limnol Oceanogr 42:282-288

Hewitt JE, Cummings VJ, Ellis JI, Funnell G, Norkko A, Talley TS, Thrush SF (2003) The role of waves in the colonisation of terrestrial sediments deposited in the marine environment. J Exp Mar Biol Ecol 290:19-47

Lundquist CJ, Pilditch CA, Cummings VJ (2004a) Behaviour controls post-settlement dispersal by the juvenile bivalves Austrovenus stutchburyi and Macomona liliana. J Exp Mar Biol Ecol 306:51-74

Lundquist CJ, Thrush SF, Oldman JW, Senior AK (2004b) Limited transport and recolonization potential in shallow tidal estuaries. Limnol Oceanogr 49:386-395

Nielsen P (1992) Coastal bottom boundary layers and sediment transport. World Scientific, Singapore

Norkko A, Bonsdoff E (1996) Population responses of coastal zoobenthos to stress induced by drifting algae mats. Mar Ecol Prog Ser 140:141-151 
Norkko A, Cummings VJ, Thrush SF, Hewitt JE, Hume T (2001) Local dispersal of juvenile bivalves: implications for sandflat ecology. Mar Ecol Prog Ser 212:131-144

Norkko A, Thrush SF, Hewitt JE, Cummings VJ and 5 others (2002) Smothering of estuarine sandflats by terrigenous clay: the role of wind-wave disturbance and bioturbation in site-dependent macrofaunal recovery. Mar Ecol Prog Ser 234:23-41

Pridmore RD, Thrush SF, Wilcock RJ, Smith TJ, Hewitt JE, Cummings VJ (1991) Effect of the organochlorine pesticide technical chlordane on the population structure of suspension and deposit feeding bivalves. Mar Ecol Prog Ser 76:261-271

Roper DS, Pridmore RD, Thrush SF (1992) Recruitment to the macrobenthos of Macomona liliana (Bivalvia: Tellinidae) in Manukau Harbour, New Zealand. NZ J Mar Freshw Res 26:385-392

Shull DH (1997) Mechanisms of infaunal polychaete dispersal and colonization in an intertidal sandflat. J Exp Mar Biol Ecol 55:153-179

Thrush SF, Whitlatch RB (2001) Recovery dynamics in benthic communities: balancing detail with simplification. In: Reise K (ed) Ecological comparisons of sedimentary shores. Springer-Verlag, Berlin, p 297-316

Thrush SF, Pridmore RD, Hewitt JE, Cummings VJ (1991) Impact of ray feeding disturbances on sandflat macrobenthos: Do communities dominated by polychaetes or shellfish respond differently? Mar Ecol Prog Ser 69:245-252

Thrush SF, Whitlatch RB, Pridmore RD, Hewitt JE, Cummings VJ, Wilkinson MR (1996) Scale-dependent recolonization: the role of sediment stability in a dynamic sandflat habitat. Ecology 77:2472-2487

Thrush SF, Hewitt JE, Cummings VJ, Dayton PK and 6 others (1998) Disturbance of the marine benthic habitat by commercial fishing: impacts at the scale of the fishery. Ecol
Appl 8:866-879

Thrush SF, Hewitt JE, Norkko A, Cummings VJ, Funnell GA (2003) Macrobenthic recovery processes following catastrophic sedimentation on estuarine sandflats. Ecol Appl 13:1433-1455

Turner SJ, Grant J, Pridmore RD, Hewitt JE, Wilkinson MR, Hume TM, Morrisey DJ (1997) Bedload and water-column transport and colonization processes by post-settlement benthic macrofauna: Does infaunal density matter? J Exp Mar Biol Ecol 216:51-75

Verdier-Bonnet C, Carlotti F, Rey C, Bhaud M (1997) A model of larval dispersion coupling wind-driven currents and vertical larval behaviour: application to the recruitment of the annelid Owenia fusiformis in Banyuls Bay, France. Mar Ecol Prog Ser 160:217-231

Vogel S (1994) Life in moving fluids, 2nd edn. Princeton University Press, Princeton, NS

Whitlatch RB, Lohrer AM, Thrush SF, Pridmore RD, Hewitt JE, Cummings VJ, Zajac RN (1998) Scale-dependent benthic recolonization dynamics: life stage-based dispersal and demographic consequences. Hydrobiologia 375/376:217-226

Zajac RN, Whitlatch RB (1982a) Responses of estuarine infauna to disturbance. I. Spatial and temporal variation of initial recolonization. Mar Ecol Prog Ser 10:1-14

Zajac RN, Whitlatch RB (1982b) Responses of estuarine infauna to disturbance. II. Spatial and temporal variation of succession. Mar Ecol Prog Ser 10:15-27

Zajac RN, Whitlatch RB (2003) Community and populationlevel responses to disturbance in a sandflat community. J Exp Mar Biol Ecol 294:101-125

Zajac RN, Whitlatch RB, Thrush SF (1998) Recolonization and succession in soft-sediment infaunal communities: the spatial scale of controlling factors. Hydrobiologia 375/376: $227-240$

Appendix 1. Bonferroni post hoc tests to support results of generalised linear modelling on the effect of site and weather on the number of macrofauna, number of taxa and sediment weight collected in sediment traps at 3 different heights (Table 4). Results of significant differences between sites are shown for $\mathrm{p}<0.05$

\begin{tabular}{|c|c|c|c|c|c|c|c|c|}
\hline \multicolumn{9}{|c|}{ Number of macrofaunal individuals } \\
\hline Offshore & Bed & 4 & 2 & 3 & 5 & 1 & 6 & 7 \\
\hline Onshore & Bed & 5 & 4 & 2 & 1 & 3 & 6 & $\underline{7}$ \\
\hline Offshore & $5 \mathrm{~cm}$ & 3 & 5 & 4 & 2 & 6 & 1 & 7 \\
\hline Onshore & $5 \mathrm{~cm}$ & 2 & 1 & 4 & 5 & 3 & 6 & 7 \\
\hline Offshore & $15 \mathrm{~cm}$ & 3 & 5 & 2 & 4 & 6 & 1 & 7 \\
\hline Onshore & $15 \mathrm{~cm}$ & 5 & 4 & 1 & 3 & 2 & $\underline{6}$ & 7 \\
\hline
\end{tabular}


Appendix 1 (continued)

Number of macrofaunal taxa

\begin{tabular}{|c|c|c|c|c|c|c|c|c|}
\hline Offshore & Bed & 2 & 4 & 3 & 5 & 1 & 6 & 7 \\
\hline Onshore & Bed & 2 & 4 & 5 & 1 & 3 & 6 & 7 \\
\hline Offshore & $5 \mathrm{~cm}$ & 5 & 3 & 4 & 2 & 6 & 1 & 7 \\
\hline Onshore & $5 \mathrm{~cm}$ & 2 & 4 & 1 & 5 & 3 & 6 & 7 \\
\hline Offshore & $15 \mathrm{~cm}$ & 5 & 3 & 4 & 2 & 6 & 1 & 7 \\
\hline Onshore & $15 \mathrm{~cm}$ & 5 & 4 & 3 & 2 & 1 & 6 & 7 \\
\hline
\end{tabular}

Sediment weight

\begin{tabular}{|c|c|c|c|c|c|c|c|c|}
\hline Offshore & Bed & 5 & 2 & 4 & 1 & 6 & 3 & 7 \\
\hline Onshore & Bed & 2 & 5 & 1 & 4 & 6 & 3 & 7 \\
\hline Offshore & $5 \mathrm{~cm}$ & 4 & 5 & 2 & 6 & 1 & 3 & 7 \\
\hline Onshore & $5 \mathrm{~cm}$ & 2 & 5 & 1 & 4 & 6 & 3 & 7 \\
\hline Offshore & $15 \mathrm{~cm}$ & 6 & 4 & 1 & 5 & 2 & 3 & 7 \\
\hline Onshore & $15 \mathrm{~cm}$ & 5 & 1 & 6 & 2 & 4 & 7 & 3 \\
\hline
\end{tabular}

Ratio of number of macrofauna in traps to ambient cores

\begin{tabular}{lllllllll} 
Offshore & Bed & 4 & 3 & 2 & 1 & 5 & 6 & 7 \\
\cline { 3 - 7 } Onshore & Bed & 5 & 2 & 4 & 1 & 3 & 6 & 7 \\
\cline { 3 - 8 } Offshore & $5 \mathrm{~cm}$ & 3 & 5 & 4 & $\underline{2}$ & 6 & 1 & 7 \\
\cline { 3 - 8 } Onshore & $5 \mathrm{~cm}$ & 1 & 2 & 5 & 4 & 3 & 6 & 7 \\
\cline { 3 - 8 } Offshore & $15 \mathrm{~cm}$ & 3 & 5 & 2 & 4 & 6 & 1 & 7 \\
\cline { 3 - 8 } Onshore & $15 \mathrm{~cm}$ & 5 & 1 & 4 & 2 & 3 & 6 & 7
\end{tabular}

Editorial responsibility: John Gray (Contributing Editor), Oslo, Norway
Submitted: October 7, 2005; Accepted: March 29, 2006

Proofs received from author(s): October 2, 2006 